\title{
INVESTIGATING TANZANIA GOVERNMENT EMPLOYEES' ACCEPTANCE AND USE OF SOCIAL MEDIA: AN EMPIRICAL VALIDATION AND EXTENSION OF UTAUT
}

\author{
Julius Raphael Athuman Mhina, Md Gapar Md Johar \\ Management \& Science University, Faculty of Information Sciences \& Engineering, \\ Shah Alam, Selangor, Malaysia
}

\begin{abstract}
The aim of this paper was to present factors which influence work-related adoption of social media among government employees. The study adapted the Unified Theory of Acceptance and Use of Technology (UTAUT) and integrated it with three constructs namely Hedonic Motivation (HM), Perceived Personal Image (PI) and Attitude (AT). The sample of study consisted of 600 usable responses collected using survey questionnaire from employees based in Tanzania Ministries, Departments and Agencies (MDAs) employing convenience sampling technique. The data was analyzed using Structural Equation Modelling. The results showed that, PI and HM influence attitude (AT), while PI, Social Influence (SI) and AT influence Behavior Intention (BI). Moreover, SI, PI, AT and BI showed significant effect on actual Use Behavior. Furthermore, the results showed that PI is affected positively by HM and SI. The added constructs proved to be important modifications to the UTAUT model as suggested by the increase in explained variance by UTAUT from $70 \%$ to $73 \%$ on BI and from $53 \%$ to $73 \%$ on actual use behavior.
\end{abstract}

\section{KEYWORDS}

Web 2.0 and Social Media, Hedonic Motivation, Perceived Personal Image, Attitude, UTAUT, Government Employee, Tanzania.

\section{INTRODUCTION}

There is a substantial evidence suggesting that social media are widely and increasingly being used by people of all demographic classes [1][2]. A special report by Kemp [3] revealed that, as of January, 2018, out of 7.593 billion total world population; 5.135 (68\%) billion were unique mobile phone users, 4.021 (53\%) billion were internet users, 3.191 (42\%) billion were active social media users and $2.958(39 \%)$ billion were active mobile social media users. The report further reports that an average internet user spends, on average 6 hours per day online. Moreover, the report reveals that about 200 million people used internet for the first time in 2017 with Africa recording the fastest growth rate, in which the number of internet users across the continent is increasing by $20 \%$ per year. Overall, the report shows that, the global number of social media users has increased by $13 \%$ in the last the past year and this staggering increase in internet users is associated with the increasingly affordable smartphones and mobile data plans.

Studies show that, in response to the large number of citizens using social media, government organizations are increasingly adopting social media [4]-[7] hence making social media a key component of electronic government (hereafter called e-government). Use of social media in e- 
International Journal of Managing Information Technology (IJMIT) Vol.10, No.2, May 2018

government increases government-citizen engagement [8], fosters citizens' electronic participation [9], increases government transparency [10], strengthens the communication, interaction and collaboration between government and stakeholders [11] and increases citizens' trust in the government [12].

A study conducted by Dwivedi et al., [13] showed that there are many studies on use of social media in electronic government. However, most of the studies did not employ well established theories [13]. This may be due to a lack of well suited model or theory for acceptance and use of social media in electronic government as social media is relatively a new phenomenon hence calling for a new model to suit this kind of technologies. Moreover, for social media use in government to be successful, the technologies should be accepted by the employees. However, the factors influencing government employees to use social media for work-related purposes are not well known [14].

Therefore, the main objective of this paper was to empirically validate UTAUT and integrate it with Hedonic Motivation, Perceived Personal Image and Attitude in order to study the factors that influence government employee's adoption of web 2.0 and social media applications for work-related purposes as a pre-step toward developing a model for acceptance and use of social media among government employees. These three constructs emerged in the literature to be important antecedents of technology acceptance [15]. The sample for the current study was obtained from Tanzania government employees based in Ministries, Departments and Agencies (MDAs).

This paper proceeds as follows; In section 2- literature review, section 3- Model development and hypotheses formulation, section 4- research methodology, section 5- analysis of the results, section 6 - discussion and conclusion, Section 7- further work, section 8- references and Appendices in section 9.

\section{LITERATURE REVIEW}

UTAUT is a unified model for adoption of information systems which was developed by Venkatesh et al. [16] from other eight technology adoption models. It was developed with the aim of providing a standard theoretical framework for individual adoption of technology in organizations by combining the following theories/models: Theory of Reasoned Action, Technology Acceptance Model, Motivation Model, Theory of Planned Behavior , Combined TAM and TPB, Model of Personal Computer Utilization, Innovation Diffusion Theory, Social Cognitive Theory [16].The UTAUT showed highest total explained variance on Behavior Intention (BI) (70\%) and on Use Behavior (UB) (53\%) among the eight from which it was synthesized [16].

Since its development, UTAUT has been applied in a variety of contexts such as in mobile learning [17]-[19], e-learning [20], consumer [21], e-government [22] [23], mobile commerce and internet banking [24] [25], citizens [26], research [27], Citizens' Facebook use [28] [29] and small businesses [30].

However, Venkatesh, Thong and $\mathrm{Xu}$ [31] reviewed the use of UTAUT model from when it was developed in 2003 to 2014 and concluded that the model needs refinement. Their study involved 1,267 research papers published in major information system journals and classified the papers into four themes: 1) general citation of to the original UTAUT without any substantial use of the theory $(1,205), 2$ ) an application of UTAUT as underlaying research theory in an empirical study $(12), 3)$ an integration of UTAUT with other theories (13), and 4) an extension to the UTAUT by 
International Journal of Managing Information Technology (IJMIT) Vol.10, No.2, May 2018

adding another construct (37). Looking at the number of studies which used UTAUT as their base model excluding the general citations, it shows that that there are relatively small number of studies i.e. 62 which used UTAUT as a base model contrary to the original expectation of the model development as it was expected to be a standard theory for studying adoption of information systems among researchers hence suggesting a need to refine the model [16] [31].

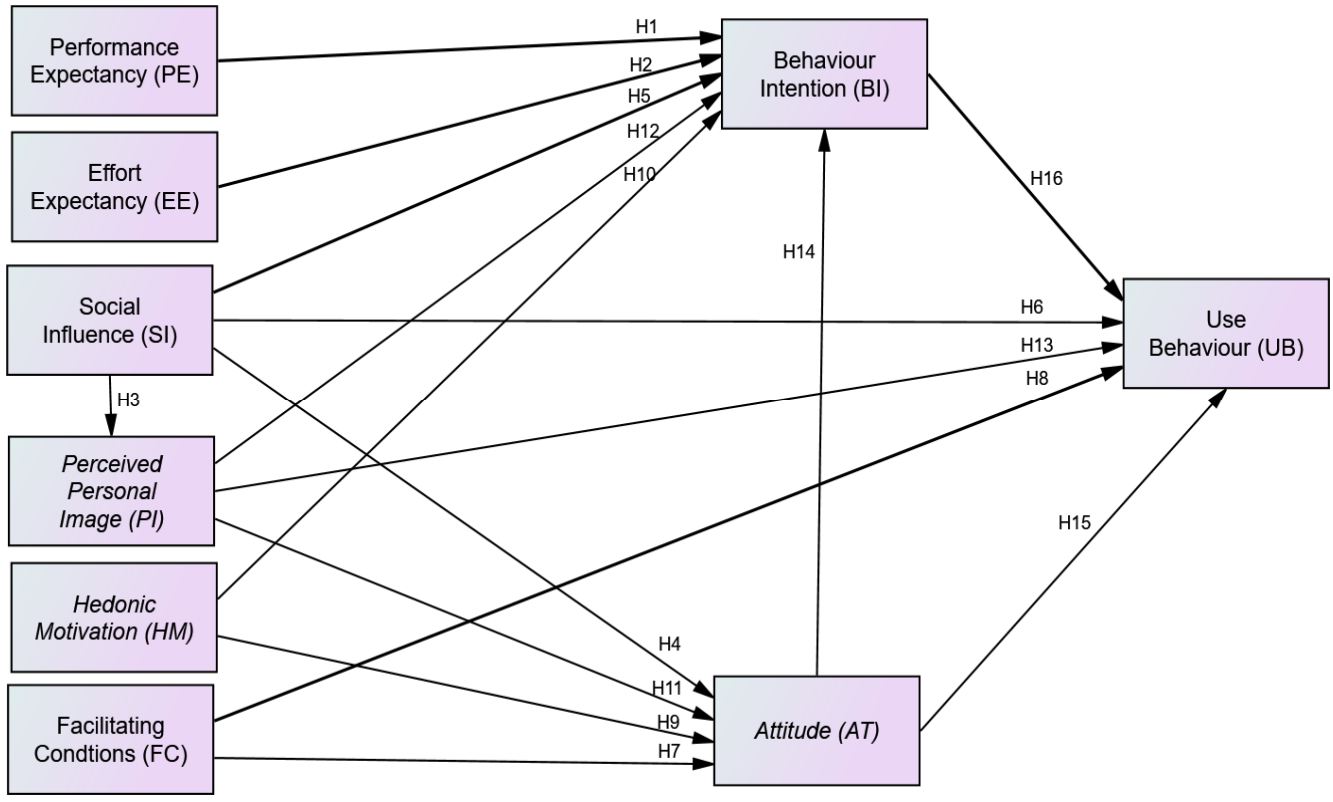

Figure 1 : Proposed Research model [Modified UTAUT]

In line with the Venkatesh et al., [31] call for need to refine the UTAUT theory, in this study we therefore seek to validate and refine the theory by integrating it with three constructs namely Hedonic Motivation, Perceived Personal Image and Attitude. There is substantial evidence from the literature which suggest that these constructs are important antecedents of intention and use of technology [14] [15].

\section{Model Development And Hypotheses Formulation}

This study adapts UTAUT model and integrate it with Hedonic Motivation (HM) and Attitude (AT) (see Figure 1). The proposed research model consists of eight (8) constructs namely; Performance Expectancy (PE), Effort Expectancy (EE), Social Influence (SI), Facilitating Conditions (FC), Hedonic Motivation (HM), Perceived Personal Image (PI), Attitude (AT), Behavior Intention (BI) and Use Behavior (UB). While the UTAUT relationships are shown using thick lines, the added constructs are written in italic. In the proposed model, Behavior Intention (BI) is postulated to be determined by PE, EE, SI, HM, PI and AT while AT is determined by SI, FC, PI and HM. Furthermore, the UB is postulated to be determined by SI, FC, AT, PI and BI and PI is determined by SI. While the UTAUT relationships are shown using thick lines, the added constructs are written in italic. In the proposed model, Behavior Intention (BI) is postulated to be determined by PE, EE, SI, HM, PI and AT. AT on the other hand is postulated to be determined by SI, FC, PI and HM. Furthermore, the UB is postulated to be determined by SI, FC, AT, PI and BI. Furthermore, the model posits that PI is determined by SI. In this study, the moderating variables of gender, age, experience and voluntariness were not analyzed. The hypotheses for this model are explained in the next subsections. 


\subsection{Performance Expectancy (PE)}

In this study, PE is defined as the degree to which a government employee believes that using social media for work-related purposes will enhance his/her job performance [16]. Apart from Venkatesh et al., [16] who found that PE positively affects BI (see figure 1), other researchers also confirmed influence of PE on acceptance of technology [14] [15] [18] [19] [29] [32] [33]. However, PE was not found to have any significant effect on BI in the following studies [17] [22]. Hence this study empirically tests the following hypothesis:

H1 Performance Expectancy has significant and direct effect on intention of government employee to adopt and use social media for work-related purposes.

\subsection{EFFORT EXPECTANCY (EE)}

In this study, Effort Expectancy (EE) is defined as the perception that using social media is ease ([16]). As shown in figure 1, EE was found to have significant and positive influence on employee's intention to adopt the new technology in [16]. Other researchers found similar results [15] [18] [22] [33]. However, EE was not found to significantly effect BI in the following studies [19] [29] [33]. Hence this study empirically tests the following hypothesis:

H2 Effort Expectancy has significant and direct effect on intention of employees to adopt and use social media for work-related purposes.

\subsection{SOCIAL INFLUENCE (SI)}

In this study SI is defined as the degree to which government employee's adoption of social media is influenced by the pressure from other people he/she deems important [16]. Previous studies show that SI has significant positive effect on employees' intention to adopt technology [14] [15] [16] [19] [29] [32] [33] and on actual use [29]. Also, SI was found to have significant effect on attitude in the following studies [15] [19]. Furthermore, social norms (similar to social influence) has shown significant positive effect on user's image (here called perceived personal image) [51]. However, SI was not found to have any significant effect on BI in the following study [18] as suggested by the UTAUT findings. Nevertheless, based on the findings of majority of studies, we hypothesize that:

H3 SI has positive significant effect on perceived personal image of a government employee to use social media for work-related purposes.

H4 SI has positive significant effect on attitude of a government employee to use social media for work-related purposes.

H5 SI has positive significant effect on intention of employees to use social media for workrelated purposes.

H6 SI has positive significant effect on government employee's actual use of social media for work-related purposes. 
International Journal of Managing Information Technology (IJMIT) Vol.10, No.2, May 2018

\subsection{Facilitating Conditions (FC)}

Facilitating Conditions (FC) is defined as the individual belief that an organizational and Technical infrastructure exists to support the use of the system [16]. In this study, FC is defined as the belief that there is enough organizational support toward use of social media for workrelated purposes. It includes supportive organizational policies, trainings and other technical assistance that may be required by an employee in order to engage in work-related use of the technologies. Previous studies show that FC has significant effect on actual use of technology [15] [16] [21] [29] [33]. Also, FC is found to have significant direct effect on attitude [14] [15]. However, the following study did not find any significant effect of FC on UB [22]. Based on majority of findings, we hypothesize that:

H7 FC have positive significant effect on Attitude of government employees to use social media for work-related purposes.

H8 FC have significant and direct effect on government employee's actual use of social media for work-related purposes.

\subsection{Hedonic Motivation (HM)}

Hedonic Motivation Hedonic motivation is defined as the perceived enjoyment, fun or pleasure experienced when using the technology [21]. In this study hedonic motivation is defined as perceived enjoyment anticipated up on use of social media. Previous studies show that hedonic motivation has positive significant influence on attitude to use a technology [34]. Also, HM was found to have significant effect on intention to use technology in the following studies [21], [29], [32]. Hence, we hypothesize that:

H9 HM has significant positive effect on the attitude of a government employee toward use of social media for work-related purposes.

H10 HM has significant positive effect on the intention of a government employee to use social media for work-related purposes.

\subsection{Perceived Personal Image (PI)}

This construct has its roots in the construct called self-identity expressiveness [36]. Personal image or Self-image is defined as the degree to which use of an innovation is perceived to enhance one's image or status in one's social system [52]. Social media enable employees to engage rapidly and simultaneously with peers, colleagues, customers, and the general public thereby offering possibilities to convey a favorable image of the self [36]. Studies show that, if important members among an individual's circle of friends believe that the person should use an innovation, then using it will improves his/her standing within this social system [52]. Empirical evidence show that self-identity has effect on both attitude and intention to engage in behavior [14]. In another study, it was found that, self-expressiveness (here called perceived personal image) has significant positive effect on actual use of social media for work-related purposes [36]. Hence, we hypothesize that: 
International Journal of Managing Information Technology (IJMIT) Vol.10, No.2, May 2018

H11 PI has positive influence on the Attitude of a government employee toward intention to engage in use of personal social media for work-related purposes.

H12 PI has positive influence on the government employee's intention to engage in use of personal social media for work-related purposes.

H13 PI has positive influence on the government employee's intention to engage in use of personal social media for work-related purposes

\subsection{Attitude (AT)}

Attitude is defined as an individual's positive or negative feelings (evaluative affect) about performing the target behavior [35]. In this study, attitude is defined as the government employee's positive or negative feelings about using personal social media accounts for workrelated. Previous studies show that attitude is an important antecedent of intention to adopt new technology [14] [15] [36]. Also, studies show that apart from having direct positive effect on BI, also attitude has direct influence on actual use [14] [15]. Hence, we propose the following hypotheses for this study:

H14 Attitude of a government employee toward social media has positive influence on his/her intention to adopt them for work-related purposes.

H15 Attitude of government employee toward social media has positive influence on his/her actual use of such technologies for work-related purposes.

\subsection{Behavior Intention (BI)}

$\mathrm{BI}$ is defined as a "degree to which a person has formulated conscious plans to perform or not perform some specified future behavior" [37]. Studies show that BI is an immediate predictor of actual use behavior [16] [35] [38] and that it has significant positive effect on actual use of technology [15] [29] [33] [36]. Hence this study assesses the willingness of government employees to engage in use of personal social media accounts for work-related purposes as an important antecedent of actual use behavior.

H16 Behavior Intention has positive significant effect on government employees' actual use of personal social media for work-related purposes.

\subsection{USE BEHAVIOR (UB)}

This is the target behavior in this study. It is the actual use of the systems. In this study it is defined as the actual use of personal social media accounts for work-related purposes. It involves posting work-related messages on web 2.0 or social media platforms such as Twitter, Facebook, YouTube, WhatsApp, LinkedIn, Instagram etc. [36]. In this study, use behavior is measured through self-reported frequency of using personal social media accounts for work-related purposes. 


\section{RESEARCH MethodologY}

\subsection{Population, Sample Size and Sampling Technique}

The population for this study is government employees based in Tanzania Ministries, Departments and Agencies (MDAs). These employees were selected because they were considered the key people toward implementation of government policies. Depending on the findings of the study, the government policies can be developed or reviewed to enhance beneficial usage of social media among government employees. Since the population size is finite and known, the Yamane formula [39] was used to calculate the sample size for the study in which 400 is considered adequate minimum sample. For this study, a Quantitative technique [40] using self-administered questionnaire [41] was employed. The convenient sampling technique was used to distribute questionnaire to 1061respondents in the following distribution: nine (9) Ministries, eighteen (18) Government Departments and five (5) Agencies based in Dar es salaam city, Tanzania. 675 (63.6\%) questionnaires were returned. After data screening, 600 usable cases were obtained. The data collection was conducted between January 2016 and March 2017. Before the actual data collection, a pilot study was conducted to fine tune the research instruments.

Table 1 : Respondents' Social Media Usage $(\mathbf{N}=675)$

\begin{tabular}{l|l|l|l}
\hline $\begin{array}{l}\text { Proffered Social } \\
\text { Media for } \\
\text { personalpurpose }\end{array}$ & Frequency & Percentage & $\begin{array}{l}\text { \% of } \\
\text { Cases }\end{array}$ \\
\hline WhatsApp & 613 & $21.40 \%$ & $91.90 \%$ \\
\hline Facebook & 474 & $16.50 \%$ & $71.10 \%$ \\
\hline YouTube & 408 & $14.20 \%$ & $61.20 \%$ \\
\hline Instagram & 356 & $12.40 \%$ & $53.40 \%$ \\
\hline Twitter & 219 & $7.60 \%$ & $32.80 \%$ \\
\hline Google Plus & 199 & $6.90 \%$ & $29.80 \%$ \\
\hline LinkedIn & 185 & $6.40 \%$ & $27.70 \%$ \\
\hline Blogs & 179 & $6.20 \%$ & $26.80 \%$ \\
\hline Skype & 177 & $6.20 \%$ & $26.50 \%$ \\
\hline WeChat & 33 & $1.20 \%$ & $4.90 \%$ \\
\hline Other & 21 & $0.70 \%$ & $3.10 \%$ \\
\hline None & $\mathbf{5}$ & $\mathbf{0 . 2 0} \%$ & $\mathbf{0 . 7 0 \%}$ \\
\hline
\end{tabular}




\subsection{Instrument Design and Development}

The initial measurement instrument used in the study consisted of 38 items (See Appendix A) with all of the items adapted from the literature. While the items for the following constructs PE, EE, SI, FC, AT and BI were adapted from Venkatesh et al. [16]; the items for HM were adapted from Venkatesh et al., [21]. Modification was done on the items to fit the area of study. A 7-point Likert scale was adapted in this study with scores ranging from 1- Strongly Disagree to 7-Strongly Agree. The validated questionnaire consisted of twenty-eight (28) items (see Appendix A).

\subsection{Study procedure}

Table 1 shows the home or personal usage of social media by respondents. Respondents were presented with a list of most popular web 2.0 and social media applications in Tanzania and were asked to indicate the application (s) they use for personal purposes whereby the most popular social media among the respondents is WhatsApp (21.1\%) which is used by $555(92.2 \%)$ respondents, Facebook is the second most used application (16.4\%) used by $432(71.8 \%)$ respondents, YouTube (14.2\%) ranked third and is used by $408(61.2 \%)$ respondents, Instagram (12.4\%) used by $356(53.4 \%)$ respondents, Twitter (7.6) used by 219 (32.8\%) respondents, LinkedIn (6.4) used by $185(27.7 \%)$ respondents, Google+ (6.9\%) used by $199(29.8 \%)$ respondents, Blogs $(6.2 \%)$ used by $179(26.8 \%)$ respondents. An almost negligible number of respondents $5(0.2 \%)$ indicated that they don't use any social media for any purpose. Those respondents who used at least one application for home or personal purposes, were asked to indicate their perception on the web 2.0 and social media applications and their willingness to use them for professional or work-related purposes.

\section{RESUltS \& ANALYSIS}

SEM technique was employed to conduct multivariate statistical analysis as it is a robust technique for analyzing multi-interrelationships between latent variables [43]. A two-stage analysis was adapted, starting with analysis of the measurement model through confirmatory factor analysis (CFA) followed by analysis of the structural model [46]. AMOS version 21 and SPSS version 21 tools were used to facilitate the analysis process.

\subsection{Descriptive Analysis}

Table 2shows demographic characteristics of the sample with $209(31 \%)$ respondents coming from Ministries, 331 (49\%) respondents from government departments and 135 (20\%) from government agencies. The youth age group (18-35) contributes more than half of the sample 376 (55.7\%). Majority of the respondents are males 338 (57.7\%), More than half of the respondents have a bachelor degree 369 (54.7) and 545 (80.8\%) have high experience ( $\geq 3$ years) in using social media for personal purposes.

\subsection{Missing Data, Normality and Outlier Assessment}

Data screening was performed on the collected data for detection of missing values, normality and outliers in order to produce valid and reliable results [42]. This process resulted in deletion of 75 cases due to high missing rate (more than 5\%) and suspicious pattern such as nonengagement [43]. The remaining data with missing values (less than 5\%) were imputed using 
International Journal of Managing Information Technology (IJMIT) Vol.10, No.2, May 2018

median [44]. The data screening process resulted into $600(88.9 \%)$ usable cases which were used in all subsequent analyses.

Univariate normality was tested by using Skewness and Kurtosis. The results of the analysis are as shown in Table 3 in which the Skewness and Kurtosis values of all items were within the acceptable value of \pm 2 for Skewness and \pm 3 for Kurtosis [45].

Table 2: Respondents demographic profile $(\mathrm{N}=675)$

\begin{tabular}{|c|c|c|c|c|}
\hline Gender & Education level & Age & Sector & Experience \\
\hline \multirow[t]{2}{*}{$\begin{array}{l}\text { Male: } 338 \\
(57.5 \%)\end{array}$} & $\begin{array}{l}\text { Diploma: } \\
(14.1 \%)\end{array}$ & $\begin{array}{l}18-35: 376 \\
(55.7 \%)\end{array}$ & $\begin{array}{l}\text { Ministry: } 209 \\
(31 \%)\end{array}$ & $\begin{array}{l}\text { Less than } 3 \\
\text { years:106(21.2\%) }\end{array}$ \\
\hline & $\begin{array}{l}\text { Bachelor: } \\
(54.7 \%)\end{array}$ & $\begin{array}{l}36-60: 287 \\
(42.5 \%)\end{array}$ & $\begin{array}{l}\text { Department: } \\
331(49 \%)\end{array}$ & $\begin{array}{l}3 \text { to } 6 \text { years: } 236 \\
(35.0 \%)\end{array}$ \\
\hline \multirow[t]{2}{*}{$\begin{array}{l}\text { Female: } 264 \\
(39.1 \%)\end{array}$} & $\begin{array}{l}\text { Master Degree: } \\
186(27.6 \%)\end{array}$ & $\begin{array}{l}\text { Other: } \\
(0.9 \%)\end{array}$ & $\begin{array}{l}\text { Agency: } 135 \\
(20 \%)\end{array}$ & $\begin{array}{l}\text { over } 6 \text { years:309 } \\
(45.8 \%)\end{array}$ \\
\hline & $\mathrm{PhD}: 5(0.7 \%)$ & & & \\
\hline $\begin{array}{l}\text { Missing: } 23 \\
(3.4 \%)\end{array}$ & $\begin{array}{l}\text { Missing: } \\
(3.0 \%)\end{array}$ & $\begin{array}{l}\text { Missing: } 6 \\
(0.9 \%)\end{array}$ & Missing: None & Missing:24 (3.6\%) \\
\hline
\end{tabular}

\subsection{Measurement Model}

This study adapted the two-step approach in conducting analysis [46]. First, CFA was conducted in order to assess the measurement model for reliability and validity of measured items followed by analysis of structural equation model for analysis of causal relationships between model constructs. To assess the model fitness, the following model fit indices were used for both the measurement model and structural model for this study: A normed $\chi$-square ( $\chi 2 / \mathrm{df})$, Root Mean Square Error of Approximation (RMSEA); Standardized Root Mean Residual (SRMR), Comparative Fit Index (CFI) and Tuller-Lewis Index (TLI) [43] (see table 4).

A confirmatory factor analysis (CFA) was carried out to validate a pooled measurement model with 38 items. In order to attain good model, fit, ten (10) items were deleted from the initial measurement model in the following order: PE4, FC3, FC5, HM1, SI4, BI4, PI1, PI3, UB1 and EE2 due to due to low factor loading $(<0.5)$ and being redundant with other items from other constructs [43]. Also, the pair of error terms for items S1 and S3, HM2 and HM3 were constrained due to high modification index $(\mathrm{MI}>15)$ [45].

The resulting model after these modifications showed a good model fit $\left(\chi^{2} / \mathrm{df}=2.378 ;\right.$ RMSEA $=$ 0.048; SRMR $=0.0412 ;$ CFI $=0.966$, TLI $=0.959)$ (see table 4, column 4). Since all model fit indices had been achieved, then, the psychometric features of the model i.e., convergent validity, discriminant validity and constructs reliability were assessed.

Cronbach's alpha $(\alpha)$, Composite Reliability (CR), Average Variance Extracted (AVE) and Maximum Shared Variance (MSV) were all used to assess reliability, discriminant validity and convergent validity of the measurement model. For reliability to be achieved, $\alpha>0.7$ and CR should be $\geq 0.6$ or preferably $>0.7$, for convergent validity to be achieved; AVE $>0.5$ and for discriminant validity to be achieved MSV $<$ AVE [43]. Table 3 shows that all the CR for all constructs ranged from 0.766 (FC) to 0.960 (BI), the AVE ranged from 0.77 (FC) to 0.96 (BI) and all MSV<AVE. Furthermore, $\sqrt{ }$ AVE- which is shown as the diagonal value (in bold) is 
International Journal of Managing Information Technology (IJMIT) Vol.10, No.2, May 2018

greater than all values along the row and column for all constructs hence discriminant validity is achieved [45]. In order to test for multicollinearity, SPSS was used to calculate tolerance and Variance Inflation Factor (VIF). A value of tolerance value greater than 0.1 and VIF of less than 3.0 is considered good indication of absence of multicollinearity [47]. Since all VIFs were $<3$ and Tolerance $>0.1$, then it is concluded that there is no multicollinearity in the sample (see table 3). Based on this assessment, it is evident that the convergent validity, reliability and discriminant validity of the constructs have been achieved, therefore the assessment of the structural model is done in the next section. The final measurement model consisted of 28 items (See Appendix B).

Table 3: Constructs Reliability, Convergent Validity and Discriminant Validity

\begin{tabular}{|c|c|c|c|c|c|c|c|c|c|c|c|c|}
\hline & $\mathbf{C R}$ & AVE & MSV & $\mathbf{P E}$ & EE & SI & FC & HM & PI & AT & BI & UB \\
\hline $\mathbf{P E}$ & $\begin{array}{r}0.8 \\
6\end{array}$ & 0.67 & 0.33 & 0.82 & & & & & & & & \\
\hline EE & $\begin{array}{r}0.7 \\
9\end{array}$ & 0.56 & 0.31 & 0.56 & 0.75 & & & & & & & \\
\hline SI & $\begin{array}{r}0.8 \\
1\end{array}$ & 0.59 & 0.3 & 0.5 & 0.24 & 0.77 & & & & & & \\
\hline FC & $\begin{array}{r}0.7 \\
7\end{array}$ & 0.52 & 0.36 & 0.58 & 0.51 & 0.55 & 0.72 & & & & & \\
\hline $\begin{array}{l}\mathbf{H} \\
\mathbf{M}\end{array}$ & $\begin{array}{r}0.9 \\
5\end{array}$ & 0.81 & 0.36 & 0.44 & 0.28 & 0.54 & 0.6 & 0.9 & & & & \\
\hline PI & $\begin{array}{r}0.8 \\
2\end{array}$ & 0.54 & 0.51 & 0.34 & 0.11 & 0.53 & 0.41 & 0.49 & 0.73 & & & \\
\hline AT & $\begin{array}{r}0.8 \\
9\end{array}$ & 0.73 & 0.68 & 0.26 & 0.05 & 0.44 & 0.42 & 0.53 & 0.7 & 0.86 & & \\
\hline BI & $\begin{array}{r}0.9 \\
6\end{array}$ & 0.89 & 0.68 & 0.27 & 0.03 & 0.49 & 0.39 & 0.45 & 0.72 & 0.83 & 0.94 & \\
\hline UB & $\begin{array}{r}0.9 \\
1\end{array}$ & 0.84 & 0.66 & 0.31 & 0.05 & 0.55 & 0.38 & 0.48 & 0.71 & 0.78 & 0.81 & $\begin{array}{r}0.9 \\
1\end{array}$ \\
\hline \multicolumn{4}{|l|}{ VIF } & $\begin{array}{l}1.68 \\
4\end{array}$ & $\begin{array}{l}1.46 \\
8\end{array}$ & $\begin{array}{l}1.58 \\
6\end{array}$ & $\begin{array}{l}1.74 \\
0\end{array}$ & $\begin{array}{l}1.63 \\
0\end{array}$ & N/A & N/A & N/A & N/A \\
\hline \multicolumn{4}{|c|}{ Cronbach's alpha } & $\begin{array}{l}0.85 \\
4\end{array}$ & 0.77 & $\begin{array}{l}0.75 \\
8\end{array}$ & $\begin{array}{l}0.75 \\
6\end{array}$ & $\begin{array}{l}0.94 \\
9\end{array}$ & $\begin{array}{l}0.86 \\
3\end{array}$ & $\begin{array}{l}0.88 \\
9\end{array}$ & $\begin{array}{l}0.95 \\
9\end{array}$ & $\begin{array}{l}0.9 \\
1\end{array}$ \\
\hline \multicolumn{4}{|c|}{ Tolerance } & $\begin{array}{l}0.59 \\
4\end{array}$ & $\begin{array}{l}0.68 \\
1\end{array}$ & $\begin{array}{l}0.63 \\
1\end{array}$ & $\begin{array}{l}0.57 \\
5\end{array}$ & $\begin{array}{l}0.61 \\
3\end{array}$ & $\begin{array}{l}0.69 \\
8\end{array}$ & N/A & N/A & N/A \\
\hline \multicolumn{4}{|c|}{ Skewness } & -.592 & -.620 & -.201 & -.374 & -.585 & -.380 & -.300 & -.029 & $\begin{array}{l}.17 \\
2\end{array}$ \\
\hline \multicolumn{4}{|c|}{ Kurtosis } & .175 & $\begin{array}{l}1.05 \\
1\end{array}$ & -.014 & .151 & .048 & -.174 & -.498 & -.731 & 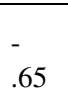 \\
\hline
\end{tabular}




\begin{tabular}{l}
\hline Notes: CR=Composite Reliability, AVE = Average Variance Extracted, MSV = Maximum Shared Variance, \\
PE=Performance Expectancy, EE=Effort Expectancy, SI = Social Influence, FC= Facilitating Conditions; HM = \\
Hedonic Motivation, PI = Perceived Personal Image, AT: Attitude; BI= Behavior Intention, UB = Use Behavior, VIF= \\
Variance Inflation Factor.
\end{tabular}

\subsection{Structural Model}

The same criteria that were used to assess goodness of fit of the measurement model were used to assess the goodness of fit (GOF) of the structural model. Both models showed similar model fit results (see table 4). Since structural model showed good model fit $\left(\chi^{2} / d f=2.375\right.$, $R M S E A=0.048, S R M R=0.0446, C F I=0.965, T L I=0.959)$, therefore path analysis can be done. The results of structural model analysis are shown in table 5 and figure 2 . The structural model results show that eleven (11) out of seventeen (17) standardized path coefficients were significant.

Table 4. Model Fit indices for the final measurement and structural model

\begin{tabular}{ll|l|l|l|l}
\hline $\begin{array}{l}\text { Name of } \\
\text { Category }\end{array}$ & $\begin{array}{l}\text { Name } \\
\text { Of } \\
\text { Index }\end{array}$ & $\begin{array}{l}\text { Recommended } \\
\text { Value }^{\mathbf{a}}\end{array}$ & $\begin{array}{l}\text { Measurement } \\
\text { Model }\end{array}$ & $\begin{array}{l}\text { Structural } \\
\text { Model }\end{array}$ \\
\hline Absolute & $\chi^{2}$ & ns at $p<0.05$ & 739.626 & 759.909 \\
\hline $\begin{array}{l}\text { Degree of } \\
\text { freedom }\end{array}$ & $d f$ & $\mathrm{n} / \mathrm{a}$ & 311 & 320 \\
\hline Parsimonious & $\chi^{2 / d f}$ & $5<$ Preferable $<3$ & 2.378 & 2.375 \\
\hline Absolute & RMSEA & $<0.08$ & 0.048 & 0.048 \\
\hline Incremental & SRMR & $<0.08$ & 0.0412 & 0.0446 \\
\hline Incremental & CFI & $>0.95$ & 0.966 & 0.965 \\
\hline Incremental & TLI & $>0.95$ & 0.959 & 0.959 \\
\hline
\end{tabular}

Notes: $\chi \mathbf{2}=$ Chi-square; $\mathbf{d f}=$ degree of freedom; RMSEA $=$ Root Mean Square Error of Approximation; SRMR= Standardized Root Mean Residual; CFI = Comparative Fit Index.

Sources: ${ }^{a}$ [43] [48] [49].

More specifically, the following factors showed significant effect on Attitude: Hedonic Motivation $(\mathrm{HM})(\beta=0.231, \mathrm{p}<0.001)$ and Perceived Personal Image (PI) $(\beta=0.581, \mathrm{p}<0.001)$ hence supporting hypotheses $\mathrm{H} 9$ and $\mathrm{H} 11$ respectively and contributed to $54 \%$ of explained variance on attitude (see table 5). However, the following hypothesized effects on attitude were not confirmed: SI $(\beta=-0.02, p>0.05)$, Facilitating Conditions (FC) $(\beta=0.042, p>0.05)$ and hence hypotheses $\mathrm{H} 4$ and $\mathrm{H} 7$ and $\mathrm{H} 10$ were not supported. Furthermore, the following factors showed significant effects on Behavior Intention (BI): Social Influence $(\mathrm{SI})(\beta=0.126, \mathrm{p}<0.01)$

Perceived Personal Image (PI) (SI) $(\beta=0.234, p<0.001)$ and Attitude (AT) $(\beta=0.646, p<0.001)$ hence showing support for the hypotheses $\mathrm{H} 5, \mathrm{H} 12$ and $\mathrm{H} 14$ and contributed to $73 \%$ of explained variance on behaviour intention (see table 5) but the findings did not support the effect of performance expectancy (PE) $(\beta=0.018, p>0.05)$, effort expectancy (EE) $(\beta=-0.053, p>0.05)$ 
International Journal of Managing Information Technology (IJMIT) Vol.10, No.2, May 2018

and Hedonic Motivation (HM) $(\beta=-0.07, p>0.05)$ on behaviour intention (BI) as hypothesized hence hypotheses $\mathrm{Hl}, \mathrm{H} 2$ and $\mathrm{HOl}$ were contradicted (see table 5).

Table 5._Structural Path Results

\begin{tabular}{|c|c|c|c|c|c|c|}
\hline HNO & Path & $(\boldsymbol{\beta})$ & S.E. & C.R. & $\begin{array}{l}\text { P- } \\
\text { Value }\end{array}$ & $\begin{array}{l}\text { Hypothesis } \\
\text { Testing }\end{array}$ \\
\hline $\mathrm{H} 3$ & $\mathrm{SI} \rightarrow \mathrm{PI}$ & 0.385 & 0.044 & 6.566 & $* * *$ & Supported \\
\hline $\mathrm{E}$ & $\mathrm{HM} \rightarrow \mathrm{PI}$ & 0.281 & 0.036 & 5.29 & $* * *$ & Emerging \\
\hline H11 & $\mathrm{PI} \rightarrow \mathrm{AT}$ & 0.581 & 0.098 & 9.567 & $* * *$ & Supported \\
\hline H9 & $\mathrm{HM} \rightarrow \mathrm{AT}$ & 0.231 & 0.055 & 4.585 & $* * *$ & Supported \\
\hline $\mathrm{H} 4$ & $\mathrm{SI} \rightarrow \mathrm{AT}$ & -0.02 & 0.063 & -0.373 & 0.709 & Unsupported \\
\hline $\mathrm{H} 7$ & $\mathrm{FC} \rightarrow \mathrm{AT}$ & 0.042 & 0.065 & 0.798 & 0.425 & Unsupported \\
\hline H1 & $\mathrm{PE} \rightarrow \mathrm{BI}$ & 0.018 & 0.055 & 0.44 & 0.66 & Unsupported \\
\hline $\mathrm{H} 2$ & $\mathrm{EE} \rightarrow \mathrm{BI}$ & -0.053 & 0.065 & -1.526 & 0.127 & pported \\
\hline $\mathrm{H} 5$ & $\mathrm{SI} \rightarrow \mathrm{BI}$ & 0.126 & 0.049 & 3.129 & 0.002 & Supported \\
\hline $\mathrm{H} 12$ & $\mathrm{PI} \rightarrow \mathrm{BI}$ & 0.234 & 0.082 & 4.672 & $* * *$ & Supported \\
\hline $\mathrm{H} 14$ & $\mathrm{AT} \rightarrow \mathrm{BI}$ & 0.646 & 0.048 & 13.598 & $* * *$ & Supported \\
\hline $\mathrm{H} 10$ & $\mathrm{HM} \rightarrow \mathrm{BI}$ & -0.07 & 0.04 & -1.959 & 0.05 & Unsupported \\
\hline $\mathrm{H} 15$ & $\mathrm{AT} \rightarrow \mathrm{UB}$ & 0.289 & 0.058 & 4.89 & $* * *$ & Supported \\
\hline H16 & $\mathrm{BI} \rightarrow \mathrm{UB}$ & 0.387 & 0.056 & 6.733 & $* * *$ & Supported \\
\hline $\mathrm{H} 8$ & $\mathrm{FC} \rightarrow \mathrm{UB}$ & -0.046 & 0.045 & -1.22 & 0.223 & Unsupported \\
\hline H6 & $\mathrm{SI} \rightarrow \mathrm{UB}$ & 0.176 & 0.049 & 4.243 & $* * *$ & Supported \\
\hline H13 & $\mathrm{PI} \rightarrow \mathrm{UB}$ & 0.156 & 0.082 & 3.015 & 0.003 & Supported \\
\hline \multicolumn{7}{|c|}{$\begin{array}{l}\text { Notes: HNO: Hypothesis Number }=\text { Emerging, PE=Performance Expectancy, } \\
\text { EE=Effort Expectancy, SI = Social Influence, FC }=\text { Facilitating Conditions; HM: } \\
\text { Hedonic Motivation, I: Perceived Personal Image, AT: Attitude, BI=Behavior } \\
\text { Intention; UB = Use Behavior; Significance levels: } * * p<0.01, * * * p<0.001 \text {; ns: } \\
\text { Not Significant }(p>0.05) ; \beta \text { : Standardized Path Coefficients. }\end{array}$} \\
\hline
\end{tabular}

On the other hand, the following factors showed significant effects on actual Use Behaviour: Social Influence $(\beta=0.176, p<0.001)$, Perceived Personal Image $(\beta=0.156, p<0.001)$, Attitude $(\beta=0.289, p<0.001)$ and Behaviour Intention $(\beta=0.387, p<0.001)$ hence showing support for the hypotheses $\mathrm{H6}, \mathrm{H13}, \mathrm{HI} 4$ and $\mathrm{H} 16$ respectively and contributed to $73 \%$ of explained variance on actual use behaviour (see table 5). However, the proposed effect of facilitating conditions on actual use behaviour could not be confirmed hence hypothesis $H 7$ was contradicted. These factors contributed to $73 \%$ of explained variance on actual use behaviour (see table 5).

Finally, the results showed that Social Influence has positive significant effect on Perceived Personal Image $(\beta=0.385, p<0.001)$ hence showing support for hypothesis H3. Also, unexpected significant relationship between hedonic motivation and perceived personal image $(\beta=0.281, p<0.001)$ as suggested by the high modification index $(\mathrm{HM})(\mathrm{HM}=16.485)$ [53]. These two factors explained up to $35 \%$ of variance on perceived personal image (see table 5). 


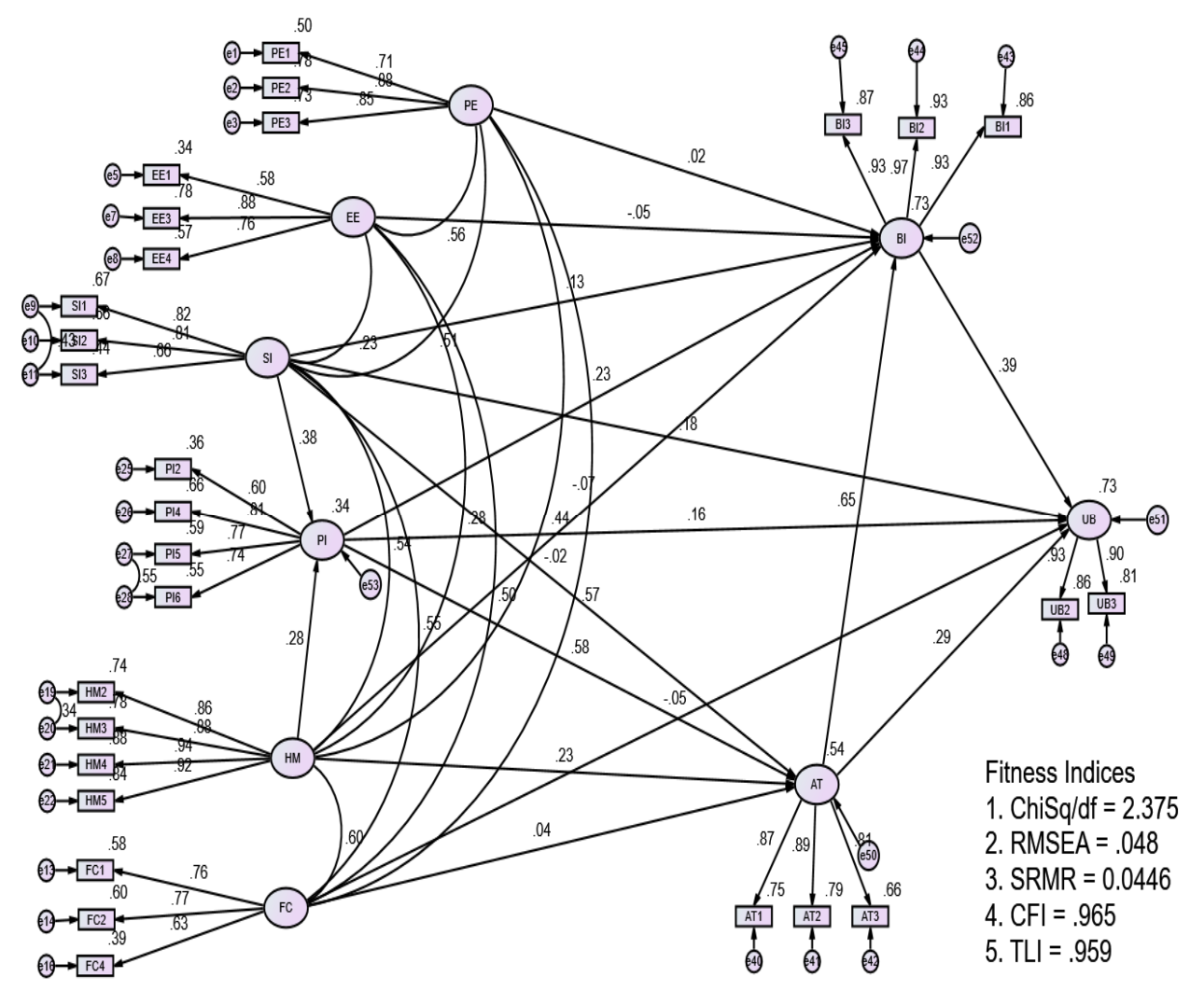

Figure 2. Structural Model Results for Proposed Model

These results show that the proposed model showed higher explained variance on Behaviour Intention (73\%) and actual Use Behaviour (73\%) than the 70\% variance on BI and 53\% on UB which was obtained by Venkatesh et al., (2003). However, our model did not include interaction terms as it was the case with the original UTAUT model. This is because the used software in this case i.e. AMOS does not support including interaction terms in the analysis. The structural model results as determined by AMOS are shown in figure 2.

\section{DISCUSSION}

The aim of this paper was to validate UTAUT and integrate it with Hedonic Motivation (HM), Perceived Personal Image (PI) and Attitude (AT) in order to investigate the antecedents of acceptance and work-related use of personal social media accounts among Tanzania government employees. The results showed that, the added constructs improved the model performance as shown by the explained variances on behavior intention and actual use.

The results showed that, attitude is the strongest determinant of intention and actual use of personal social media for work-related purposes among the respondents consistent with other studies [15] [36].

The second most important antecedent of acceptance and use social media among the respondents is perceived personal image (PI) which was found to be highly significant on attitude, behavior intention and actual use behavior. The positive effect of PI implies that, 
International Journal of Managing Information Technology (IJMIT) Vol.10, No.2, May 2018

employees will engage in use work-related use of social media if they believe that, engagement in this behavior will enhance their social image among their colleagues and society [36].

Regarding social influence, our results confirmed its effect on perceived personal image, behavior intention and actual use consistent with other previous studies [14] [15] [16] [21] and [51]. This suggests that the decision of respondents to use personal social media for work-related purposes is highly influenced by others especially the supervisors and other colleagues deemed important.

Regarding hedonic motivation, the results confirmed that perceived enjoyment i.e. hedonic motivation has positive effect on perceived personal image and attitude of respondents toward adoption of work-related use of social media. Hence employees who perceive social media as enjoyable have positive attitude toward use the technologies for work-related purposes.

However, our results could not confirm effect of Performance Expectancy (PE) and Effort Expectancy on behavior intention consistent with [17] [22] [19] [29] [33] [50] who obtained similar results regarding $\mathrm{PE}$ and $\mathrm{EE}$ respectively.

Overall, our results show that the acceptance and use of personal social media accounts for workrelated purposes among Tanzania government employee is influenced by individual or psychological factors (hedonic motivation, social influence, perceived personal image and attitude) and not by the system attributes i.e. performance expectancy and effort expectancy which in this case did not play any salient role in the intention of the employees to engage in the behavior.

\section{FURTHER WORK}

The main objective of this study was to investigate the factors that influence government employee's use of personal social media accounts for work-related purposes. Although this objective was achieved, nevertheless the model has a number of limitations that can limit its applicability. Firstly, this research was based on non-probabilistic sampling technique which could limit generalizability of the results hence in future a probabilistic sampling technique can done to offset this limitation. Secondly, this study is a cross-sectional since it was conducted in only in one point in time hence the results should be used with caution since changes in time and technology may affect the attitude of employees toward use personal social media accounts for work-related purposes.

Thirdly, the explained variance on perceived personal image (35\%), attitude (54\%), behavior intention (73\%) and use behavior (73\%) shows that there is room for improvement of the model by investigating the unidentified factors in order to achieve even higher explanatory power especially on perceived personal image and attitude in which the contributing factors showed relatively low explained variance. Fourthly, this study employed a quantitative approach in order to achieve the objectives of the study, however in future a mixed method approach can be used to provide in-depth explanation of the results. 
International Journal of Managing Information Technology (IJMIT) Vol.10, No.2, May 2018

\section{REFERENCES}

[1] Chui, M. et al. (2012) 'The social economy: Unlocking value and productivity through social technologies', McKinsey Global Institute, (July), pp. 1-18. doi: 10.1007/s11002-013-9246-1.

[2] Goncalves, J. et al. (2015) 'Increasing the Reach of Government Social Media: A Case Study in Modeling Government-Citizen Interaction on Facebook', Policy \& Internet, 7(1), pp. 80-102. doi: 10.1002/poi3.81.

[3] Kemp, S. (2018) Digital in 2018: World's internet users pass the 4 billion mark - We Are Social UK. Available at: https://wearesocial.com/uk/blog/2018/01/global-digital-report-2018 (Accessed: 17 February 2018).

[4] Magro, M. J. (2012), “A Review of Social Media Use in E-Government,”Administrative Sciences, Vol. 2 No. 4, pp.148-161.

[5] Banday,T, M., \& Mattoo, M. M. (2013),"Social Media in e-Governance: A Study with Special Reference to India", Social Networking, pp.47-56.

[6] Al-badi, A. H. (2013)," The adoption of social media in government agencies: Gulf Cooperation Council case study", Journal of Technology Research, pp.1-26.

[7] Mainka, A. et al. (2014) 'Government and social media: A case study of 31 informational world cities', Proceedings of the Annual Hawaii International Conference on System Sciences, (January), pp. 1715-1724. doi: 10.1109/HICSS.2014.219.

[8] Mossberger, K., Wu, Y. and Crawford, J. (2013) 'Connecting citizens and local governments? Social media and interactivity in major U.S. cities', Government Information Quarterly, 30(4), pp. 351-358. doi: 10.1016/j.giq.2013.05.016.

[9] Boudjelida, A., Mellouli, S. and Lee, J. (2016) 'Electronic Citizens Participation', in Proceedings of the 9th International Conference on Theory and Practice of Electronic Governance - ICEGOV'15-16. New York, New York, USA: ACM Press, pp. 31-39. doi: 10.1145/2910019.2910097.

[10] Carlo Bertot, J., Jaeger, P. T. and Grimes, J. M. (2012) 'Promoting transparency and accountability through ICTs, social media, and collaborative e-government', Transforming Government: People, Process and Policy. Edited by S. Ae Chun. Emerald Group Publishing Limited, 6(1), pp. 78-91. doi: 10.1108/17506161211214831.

[11] Al-Jamal, M. and Shanab, E. A. (2016) 'The influence of open government on e-government website: the case of Jordan', International Journal of Electronic Governance, 8(2), p. 159. doi: 10.1504/IJEG.2016.078131.

[12] Picazo-Vela, S., Gutiérrez-Martínez, I. and Felipe Luna-Reyes, L. (2012) 'Understanding risks, benefits, and strategic alternatives of social media applications in the public sector'. doi: 10.1016/j.giq.2012.07.002.

[13] Dwivedi, Y. K., Rana, N. P., Tajvidi, M., et al. (2017) 'Exploring the Role of Social Media in eGovernment', Proceedings of the 10th International Conference on Theory and Practice of Electronic Governance - ICEGOV'17, pp. 97-106. doi: 10.1145/3047273.3047374.

[14] Mhina, J.R.A and Johar,M.G.M (2017),“A conceptual Framework for Acceptance and Use of Social Media among Government Employees”, International Journal of Emerging Trends \& Technology in Computer Science, Vol. 6 No. 6,pp.181- 186. [15] Dwivedi, Y. K., Rana, N. P., Jeyaraj, A., et al. (2017) 'Re-examining the Unified Theory of Acceptance and Use of Technology (UTAUT): Towards a Revised Theoretical Model', Information Systems Frontiers. Information Systems Frontiers, pp. 116. doi: 10.1007/s10796-017-9774-y.

[16] Venkatesh, V., Morris, M. G., Davis, G. B., \& Davis, F. D. (2003), "User Acceptance of Information Technology: Toward a Unified View”, MIS Quarterly, Vol. 27 No. 3, pp.425-478.

[17] Jairak, K., Praneetpolgrang, P., \& Mekhabunchakij, K. (December, 2009),"An Acceptance of Mobile Learning for Higher Education Students in Thailand", International Journal of the Computer, the Internet and Management, Vol. 17(SP3),pp. 36.1-36.7.

[18] Nassuora, A. B. (2013),"Students Acceptance of Mobile Learning for Higher Education in Saudi Arabia”, International Journal of Learning and Management Systems, Vol. 1 No. 1, pp.1-9.

[19] Thomas, T., Singh, L., \& Gaffar, K. (2013),"The utility of the UTAUT model in explaining mobile learning adoption in higher education in Guyana”, International Journal of Education and Development using Information and Communication Technology,Vol. 9 No. 3, pp.71-85. 
International Journal of Managing Information Technology (IJMIT) Vol.10, No.2, May 2018

[20] Yoo, S. J., Han, S.-H. and Huang, W. (2012) 'The roles of intrinsic motivators and extrinsic motivators in promoting e-learning in the workplace: A case from South Korea'. doi: 10.1016/j.chb.2011.12.015.

[21] Venkatesh, V. (2012)," Consumer Acceptance and Use of Information Technology: Extending the Unified Theory of Acceptance and Use of Technology," MIS Quarterly, Vol. 36 No. 1, pp.157-178.

[22] Al-Shafi, S., \& Weerakkody, V. (2010)," Factors affecting e-government adoption in the state of Qatar", Proceedings of the European and Mediterranean Conference on Information Systems Abu Dhabi, pp.1-23.

[23] Alshehri, M. A. (2012) 'Using the UTAUT Model to Determine Factors Affecting Acceptance and Use of E-government Services in the Kingdom of Saudi Arabia', pp. 1-264.

[24] Lai, D. C. F., Lai, I. K. W., \& Jordan, E. (2009). An extended utaut model for the study of negative user adoption behaviours of mobile commerce. Proceedings of the International Conference on Electronic Business (ICEB), pp.720-728

[25] Tobergte, D. R. and Curtis, S. (2013) 'Analyzing the Use of UTAUT Model in Explaining an Online Behavior: Internet Banking Adoption', Journal of Chemical Information and Modeling, 53(9), pp. 1689-1699. doi: 10.1017/CBO9781107415324.004.

[26] Workman, M. (2013) 'New media and the changing face of information technology use: The importance of task pursuit, social influence, and experience'. doi: 10.1016/j.chb.2013.10.008.

[27] Gruzd, A., Staves, K., \& Wilk, A. (2012). Connected scholars: Examining the role of social media in research practices of faculty using the UTAUT model. Computers in Human Behavior, 28(6), 2340 2350. https://doi.org/10.1016/j.chb.2012.07.004

[28] Liew, E. J. Y., Vaithilingam, S. and Nair, M. (2014) 'Facebook and socio-economic benefits in the developing world', Behaviour \& Information Technology. Taylor \& Francis, 33(4), pp. 345-360. doi: 10.1080/0144929X.2013.810775.

[29] Lallmahomed, M. Z. I., Nor, N. Z., Ibrahim, R., \& Rahman, A. A. (2013). Predicting different conceptualizations of system use: Acceptance in hedonic volitional context (Facebook). Computers in Human Behavior, 29(6), 2776-2787. https://doi.org/10.1016/j.chb.2013.07.018

[30] Serben, D. F. (2014) 'The Examination of Factors Influencing Social Media Usage by African American Small Business Owners Using the UTAUT Model', pp. 1-134.

[31] Venkatesh, V. et al. (2016) 'Unified Theory of Acceptance and Use of Technology: A Synthesis and the Road Ahead', Jais, 17(5), pp. 328-376.

[32] Guo, Y. (2015) 'Moderating Effects of Gender in the Acceptance of Mobile SNS Based on UTAUT Model', International Journal of Smart Home, 9(1), pp. 203-216. doi: 10.14257/ijsh.2015.9.1.22.

[33] Liu, L., \& Chang, C. (2016)," Verification of Social Network Site Use Behavior of the University Physical Education Students", EURASIA Journal of Mathematics, Science \& Technology Education, Vol. 12 No. 7, pp.793-805.

[34] Tung, B. Y. E. W. et al. (2016) Determinants of Engagement in Virtual Social Networks in Singapore a Thesis Submitted in Fulfillment of the. University of Canberra.

[35] Fishbein, M., \& Ajzen, I. (1975). Belief, attitude, intention and behavior: An introduction to theory and research. Reading, MA: Addision-Wasely.

[36] van Zoonen, W., Verhoeven, J. W. M., \& Elving, W. J. L. (2014), "Understanding work-related social media use: An extension of theory of planned behavior", International Journal of Management Economics and Social Sciences, 3(4), pp.164-183.

[37] Venkatesh, V. and Bala, H. (2008) 'Technology Acceptance Model 3 and a Research Agenda on Interventions', Decision Sciences. 39(2), pp. 273-315.

[38] Ajzen, I. (1991), "The theory of planned behavior", Organizational Behavior and Human Decision Processes, Vol. 50 No. 2, pp. 179-211.

[39] Yamane, T. (1967). Statistics:AnIntroductoryAnalysis (2 ed.). New York: Harper\&Row.

[40] Creswell, J. W. (2014). Qualitative, Quantitative and Mixed Methods Research. In J. W.Creswell, Research Desig(4th ed.). Los Angeles,London,New Delhi,Singapore,Washington: SAGE.

[41] Kumar, R. (2011). Research Methodology:A step-by-step guide for beginners. London,New Delhi,California,Singapore: SAGE Publications Ltd.

[42] Tabachnick, B.G. and Fidell, L.S. (2007), Using Multivariate Statistics, 5th ed., Allyn \& Bacon, Needham Height, MA.

[43] Hair, Joseph F; Black, William C; babin, Barry J; Anderson, Rolph E;. (2010). Multivariate Data Analysis: A Global Perspective. Upper Saddle River, NJ: Person. 
International Journal of Managing Information Technology (IJMIT) Vol.10, No.2, May 2018

[44] Gaskin, J., (2016), "Data Screening", Gaskination's Statistics. https://www.youtube.com/user/Gaskination

[45] Awang, Z. (2016), SEM Made Simple: A Gentle Approach to Learning Structural Equation Modeling (2nd ed.). MPWS Rich Publication,Selangor,KualaLumpur.

[46] Schumacker, R. E., \& Lomax, R. G. (2010). A Beginner's Guide to Structural Equation Modeling. York: Routledge, Lawrence Erlbaum.

[47] Pallant, J. (2010), SPSS Survival Manual: A Step by Step Guide to Data Analysis using SPSS, 4th ed., Open University Press, Berkshire.

[48] Hu, L. and Bentler, P.M. (1999), "Cutoff criteria for fit indexes in covariance structure analysis: conventional criteria versus new alternatives", Structural Equation Modeling: A Multidisciplinary Journal, Vol. 6 No. 1, pp. 1-55.

[49] Kline, R. B. (2011). Principles and practice of structural equation modelling (3rd ed.). New York: Guilford Press.

[50] Mandal, D. and Mcqueen, R. J. (2012) 'Extending UTAUT to Explain Social Media Adoption by Microbusinesses', International Journal, 4(4), pp. 1-11. doi: 10.5121/ijmit.2012.4401

[51] Venkatesh, V. and Davis, F. D. (2000) 'A Theoretical Extension of the Technology Acceptance Model: Four Longitudinal Field Studies', Management Science. INFORMS, 46(2), pp. 186-204. doi: 10.1287/mnsc.46.2.186.11926.

[52] Moore, G. C. and Benbasat, I. (1991) 'Development of an Instrument to Measure the Perceptions of Adopting an Information Technology Innovation Instrument development-Innovation diffusionInformation technology adoption-Research methodology', Information Systems Research, 2(3), pp. 192-222.

[53] Denison, D. R., Hart, S. L., \& Kahn, J. A. (1996). From chimneys to cross-functional teams: Developing and validating a diagnostic model. Academy of Management Journal, 39(4), 1005-1024

\section{BIBLIOGRAPHY}

Julius Raphael Athuman Mhina Received B.Sc. in Computer Science from The University of Dar es Salaam in Tanzania in 2005 and M.Sc. In Advanced Computer Science from University of Sheffield in UK in 2007. He is working as assistant lecturer at the Institute of Finance management; one of the higher learning institutions in Tanzania. He is currently undertaking PhD. studies in ICT at the Management and Science University in Malaysia. His research areas of interest include: Electronic Government, Cyber Security, Social Media, Internet Programming, Software Engineering, Web Science and Operating Systems.

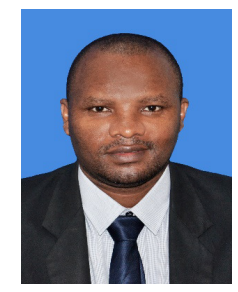

Prof. Dr. Md Gapar Md Johar He is Senior Vice President Research, Innovation, Technology and System of Management and Science University, Malaysia. He is a professor in Software Engineering. He holds $\mathrm{PhD}$ in Computer Science, MSc in Data Engineering and BSc (Hons) in Computer Science. He is a Certified E-Commerce Consultant. He has more 35 years of working experience and worked in various organizations such as Ministry of Finance, Ministry of Public Enterprise, Public Service Department, Glaxo Malaysia Sdn Bhd and Management \& Science

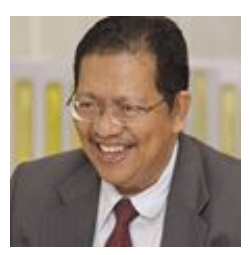
University. His research interests include learning content management system, knowledge management system, data mining, e-commerce, image processing, data science, character recognition and healthcare management system. He has developed many computerized systems such as Housing Loan Accounting System, Commercial Vehicle Licensing System, Campus Management System, Knowledge and Learning Management System, Asset and Inventory Management System, Library Information System, RFID application and Time Attendance System. 
International Journal of Managing Information Technology (IJMIT) Vol.10, No.2, May 2018

\section{Appendices}

Appendix A. Measurement Items

\begin{tabular}{|c|c|c|}
\hline Construct & $\begin{array}{l}\text { Item } \\
\text { Code }\end{array}$ & Statement \\
\hline \multirow{4}{*}{$\begin{array}{l}\text { Performanc } \\
\text { e } \\
\text { Expectancy } \\
\text { (PE) }\end{array}$} & PE1 & I find social media to be useful in my job. \\
\hline & PE2 & $\begin{array}{l}\text { Using social media for work-related purposes will enable me to } \\
\text { accomplish tasks more quickly. }\end{array}$ \\
\hline & PE3 & $\begin{array}{l}\text { Using social media for work-related purposes will increase my } \\
\text { productivity. }\end{array}$ \\
\hline & PE4 & $\begin{array}{l}\text { If I use social media for work-related purposes, I will increase } \\
\text { chances of getting my salary raised (dropped). }\end{array}$ \\
\hline \multirow{4}{*}{$\begin{array}{l}\text { Effort } \\
\text { Expectancy } \\
\text { (EE) }\end{array}$} & EE1 & My interaction with social media is clear and understandable. \\
\hline & EE2 & It is easy for me to become skillful using social media (dropped). \\
\hline & EE3 & I find it easy to use social media. \\
\hline & EE4 & Learning to operate social media is easy for me. \\
\hline \multirow{4}{*}{$\begin{array}{l}\text { Social } \\
\text { Influence } \\
\text { (SI) }\end{array}$} & SI1 & $\begin{array}{l}\text { People who influence my behavior think that I should use personal } \\
\text { social media for work-related purposes. }\end{array}$ \\
\hline & SI2 & $\begin{array}{l}\text { People who are important to me think that I should use personal } \\
\text { social media for work-related purposes. }\end{array}$ \\
\hline & SI3 & My supervisor uses personal social media for work-related purposes. \\
\hline & SI4 & $\begin{array}{l}\text { In general, my organization supports use of personal social media for } \\
\text { work-related purposes (dropped). }\end{array}$ \\
\hline \multirow{5}{*}{$\begin{array}{l}\text { Facilitating } \\
\text { Conditions } \\
\text { (FC) }\end{array}$} & $\mathrm{FC} 1$ & $\begin{array}{l}\text { I have the resources necessary to use personal social media for work- } \\
\text { related purposes. }\end{array}$ \\
\hline & $\mathrm{FC} 2$ & $\begin{array}{l}\text { I have the knowledge necessary to use personal social media for } \\
\text { work-related purposes. }\end{array}$ \\
\hline & FC3 & $\begin{array}{l}\text { Personal Social media are compatible with other technologies I use } \\
\text { (dropped). }\end{array}$ \\
\hline & $\mathrm{FC} 4$ & $\begin{array}{l}\text { I can get help from others when I have difficulties using personal } \\
\text { social media for work-related purposes. }\end{array}$ \\
\hline & FC5 & $\begin{array}{l}\text { A specific person (or group) is available for assistance with using } \\
\text { personal social media for work-related purposes (dropped). }\end{array}$ \\
\hline $\begin{array}{l}\text { Hedonic } \\
\text { Motivation }\end{array}$ & HM1 & $\begin{array}{l}\text { Using personal social media for work-related purposes would be } \\
\text { interesting (dropped). }\end{array}$ \\
\hline
\end{tabular}


International Journal of Managing Information Technology (IJMIT) Vol.10, No.2, May 2018

\begin{tabular}{|c|c|c|}
\hline \multirow[t]{4}{*}{$(\mathrm{HM})$} & HM2 & $\begin{array}{l}\text { Using personal social media for work-related purposes would be } \\
\text { enjoyable. }\end{array}$ \\
\hline & HM3 & $\begin{array}{l}\text { Using personal social media for work-related purposes would be very } \\
\text { entertaining. }\end{array}$ \\
\hline & HM4 & $\begin{array}{l}\text { Using personal social media for work-related purposes would give me } \\
\text { pleasure. }\end{array}$ \\
\hline & HM5 & $\begin{array}{l}\text { Using personal social media for work-related purposes would be } \\
\text { exciting. }\end{array}$ \\
\hline \multirow{6}{*}{$\begin{array}{l}\text { Perceived } \\
\text { Image (PI) }\end{array}$} & PI1 & I use social media to express who I want to be. \\
\hline & PI2 & I use social media to express my personal values. \\
\hline & PI3 & $\begin{array}{l}\text { People in my organization who use personal social media for work- } \\
\text { related purposes have more prestige. }\end{array}$ \\
\hline & PI4 & $\begin{array}{l}\text { People in my organization who use personal social media for work- } \\
\text { related purposes have high status. }\end{array}$ \\
\hline & PI5 & $\begin{array}{l}\text { I feel that Use of personal social media to share messages about my } \\
\text { organization will boost my image. }\end{array}$ \\
\hline & PI6 & $\begin{array}{l}\text { I feel that the Use of personal social media for sharing messages } \\
\text { about my organization will boost my status. }\end{array}$ \\
\hline \multirow{3}{*}{$\begin{array}{l}\text { Attitude } \\
\text { (AT) }\end{array}$} & AT1 & Using personal social media for work-related purposes is a good idea \\
\hline & AT2 & I would like to use personal social media for work-related purposes. \\
\hline & AT3 & $\begin{array}{l}\text { I believe that using personal social media for work-related purposes } \\
\text { would be fun. }\end{array}$ \\
\hline \multirow{4}{*}{$\begin{array}{l}\text { Behavior } \\
\text { Intention } \\
\text { (BI) }\end{array}$} & BI1 & $\begin{array}{l}\text { I intend to use personal social media for work-related purposes in the } \\
\text { next } 6 \text { months. }\end{array}$ \\
\hline & BI2 & $\begin{array}{l}\text { I predict I will use personal social media for work-related purposes in } \\
\text { the next } 6 \text { months. }\end{array}$ \\
\hline & BI3 & $\begin{array}{l}\text { I have a plan to use personal social media for work-related purposes } \\
\text { in the next } 6 \text { months. }\end{array}$ \\
\hline & BI4 & $\begin{array}{l}\text { I will always try to use personal social media for work-related } \\
\text { purposes in my daily life (dropped). }\end{array}$ \\
\hline \multirow{3}{*}{$\begin{array}{l}\text { Use } \\
\text { Behavior } \\
\text { (UB) }\end{array}$} & UB1 & $\begin{array}{l}\text { I frequently do use personal social media for work-related purposes in } \\
\text { my daily life (dropped). }\end{array}$ \\
\hline & $\mathrm{UB} 2$ & $\begin{array}{l}\text { I intensively do use personal social media for work-related purposes } \\
\text { in my daily life. }\end{array}$ \\
\hline & UB3 & Overall, I use personal social media for work-related purposes a lot. \\
\hline
\end{tabular}

Notes: Scale: $1=$ Strongly Disagree (SD); $2=$ Moderately Disagree (MD); $3=$ Disagree (D); 4 $=$ Neutral $(\mathrm{N}) 5=$ Agree $(\mathrm{A}) ; 6=$ Moderately Agree $(\mathrm{MA}) ; 7=$ Strongly Agree $(\mathrm{SA})$. 


\section{Appendix B: Final Measurement Model}

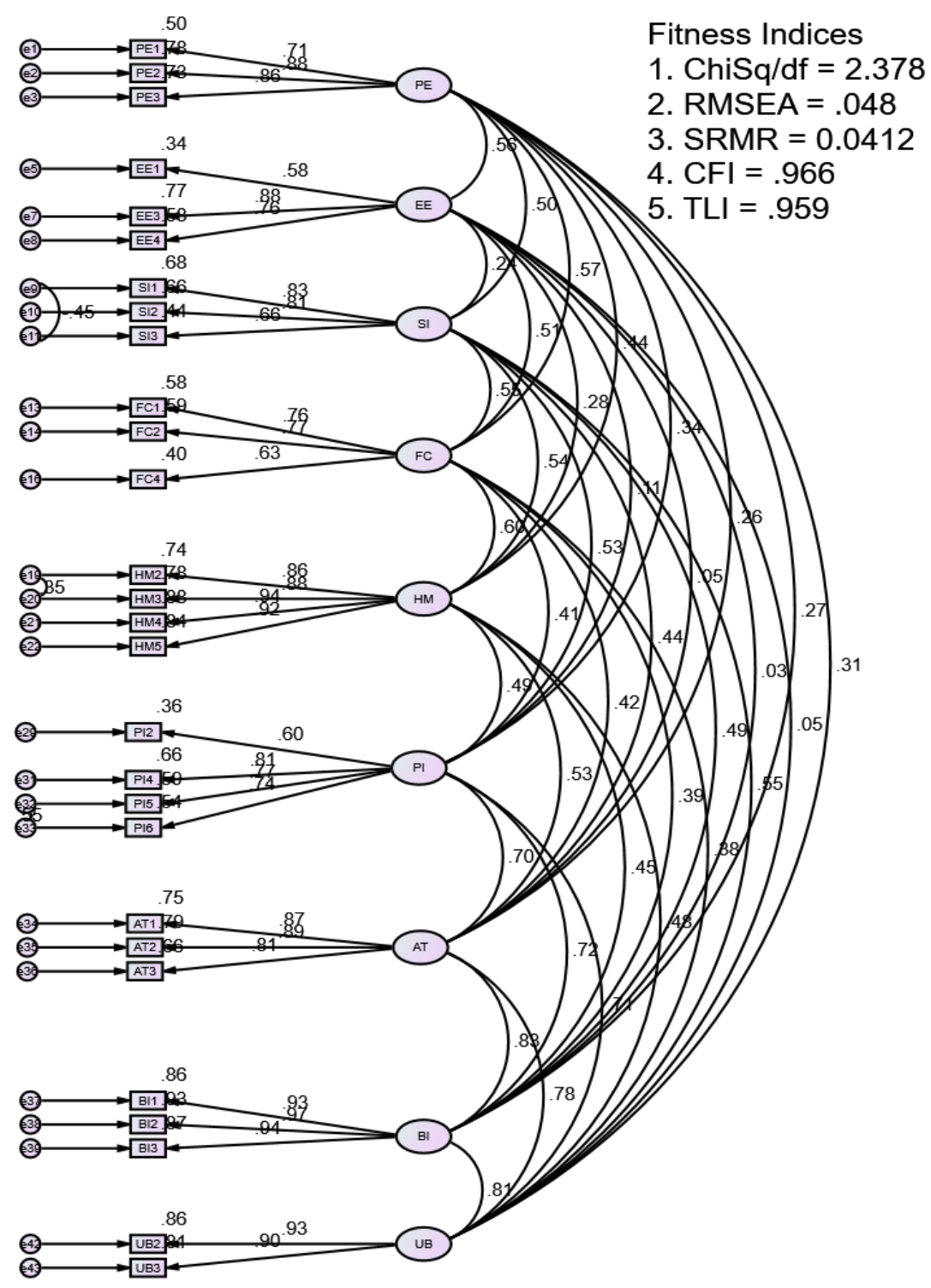

